\title{
Serosurvey of Rickettsia spp. in small mammals from Mato Grosso do Sul state, Brazil
}

\author{
Lina de Campos Binder ${ }^{*}$ Felipe da Silva Krawczak ${ }^{1}$ Jonas Sponchiado ${ }^{2}$ \\ Geruza Leal Melo ${ }^{2}$ Jonas Moraes-Filho' ${ }^{1}$ Fernanda Aparecida Nieri Bastos ${ }^{1}$ \\ Nilton Carlos Cáceres ${ }^{2}$ Marcelo Bahia Labruna ${ }^{1}$
}

${ }^{1}$ Departamento de medicina veterinária preventiva e saúde animal (VPS), Faculdade de Medicina veterinária e Zootecnia, Universidade de São Paulo (USP), Av. Prof. Dr. Orlando Marques de Paiva, 87, 05508-270, São Paulo, SP, Brasil. E-mail: lina.binder@usp.br. "Corresponding author. ${ }^{2}$ Laboratório de Ecologia e Biogeografia, Departamento de Biologia, Universidade Federal de Santa Maria (UFSM), Santa Maria, RS, Brasil.

ABSTRACT: This study aimed to evaluate exposure of wild small mammals to spotted fever group (SFG) rickettsiae in Mato Grosso do Sul State, central-western Brazil. Serum samples of 68 small mammals were analyzed by indirect immunofluorescence assay (IFA) against six Rickettsia species from Brazil. Overall, 37.5\% (9/24) marsupials and 6.8\% (3/44) small rodents were seroreactive to at least one of the Rickettsia species, with end point titres ranging from 64 to 512. These results suggested that wild small mammals were infected by SFG rickettsiae, and could participate in the ecology of rickettsiae in Mato Grosso do Sul, Brazil.

Keywords: Marsupial, Mato Grosso do Sul, Rodent; Brazilian spotted fever, IFA.

\section{Inquérito sorológico para Rickettsia spp. Em pequenos} mamíferos do estado do Mato Grosso do Sul, Brasil

RESUMO: $O$ objetivo do presente estudo foi avaliar a exposição de pequenos mamíferos silvestres para riquétsias do Grupo da Febre Maculosa (GFM) no estado do Mato Grosso do Sul, centro-oeste do Brasil. Amostras de soro de 68 pequenos mamíferos foram submetidos à reação de imunofluorescência indireta (RIFI) frente a seis espécies de Rickettsia do Brasil. No total, 37,5\% (9/24)e 6,8\% (3/44) dos soros de marsupiais e pequenos roedores, respectivamente, reagiram a pelo menos uma das espécies de Rickettsia, com títulos variando de 64 a 512. Osresultados sugerem que pequenos mamíferos silvestres foram infectados por riquétsias do GFM e poderiam participar na ecologia de riquétsias no Mato Grosso do Sul, Brasil.

Palavras-chave: marsupial, Mato Grosso do Sul, roedor; febre maculosa brasileira, RIFI.

Rickettsia rickettsii is the etiologic agent of a severe febrile illness in humans, known in Brazil as Brazilian Spotted Fever (BSF) (ANGERAMI et al.,2006). For keeping its vital cycle, $\boldsymbol{R}$. rickettsii needs a tick population and vertebrate animals, called amplifier hosts, which develop a rickettsemia for some days or weeks, to enable the infection of additional ticks. This mechanism amplifies the $\boldsymbol{R}$. rickettsii infection rates among the tick population (LABRUNA, 2009).

The urban expansion process in rural areas increases the chance of interaction of humans and domestic animals with wild animal populations, which may be infested by ticks, increasing the risk of rickettsiosis (BARBIERI et al., 2014). Small mammals are main hosts of immature stages of numerous tick species (SARAIVA et al., 2012); hence, serosurvey of these animals is very useful for predicting circulation of rickettsiae in a given area.The present study aimed to evaluate exposure of wild small mammals for spotted fever group (SFG) rickettsiae in the state of Mato Grosso do Sul (MS), central-western Brazil.

While BSF is endemic in many parts of Brazil (LABRUNA, 2009), the occurrence of this tick-borne disease in MS has been restricted to a single, laboratory-confirmed case in Dois Irmãos do Buriti municipality during 2013 (official data from the Brazilian Ministry of Health, 2016). From 2012 to 2013, SPONCHIADO et al. (2015) performed a field study in MS, in which wild small mammals were trapped in 31 woodland fragments of Cerrado biome distributed in the municipalities of Terenos, Anastácio, Miranda, Bonito, and Nioaque, located in the Paraguai River basin between the coordinates $20^{\circ} 17^{\prime}-21^{\circ} 15^{\prime} \mathrm{S}$ and $54^{\circ} 53^{\prime}-56^{\circ} 31^{\prime} \mathrm{W}$. The maximum distance between these localities was $162 \mathrm{~km}$. Because these localities are close to Dois Irmãos do Buriti (Figure 1), from 
where BSF was reported, blood samples from 68 small mammals trapped from November 2012 to July 2013 during the study of SPONCHIADO et al. (2015) were provided for the present study, in order to be tested for the presence of anti-Rickettsia spp. antibodies. While SPONCHIADO et al. (2015) sampled a much larger sample of small mammals, blood samples collected from only 68 individuals belonging to 13 different species, 4 marsupials (Didelphis albiventris-white-eared opossum, Gracilinanus agilis- agile gracile opossum, Marmosa murina - Linnaeus's mouse opossum, Thylamys macrurus- Paraguayan fat-tailed mouse opossum) and 9 rodents (Calomys callosus- large vesper mouse, C. tener- delicate vesper mouse, Cerradomys scottiLindbergh's rice rat, $\boldsymbol{C}$. maracajuensis - Maracaju rice rat, Hylaeamys megacephalus - Azara's broadheaded rice rat, Nectomys rattus - Amazonian water rat, Oecomys bicolor - bicolored arboreal rice rat, $\boldsymbol{O}$. mamorae- mamore arboreal rice rat, Rhipidomys macrurus - Cerrado climbing mouse) were tested. Overall, $75 \%(18 / 24)$ and $11 \%(5 / 44)$ of these marsupials and rodents, respectively, were reported to be infested by ticks, which were identified as immature stages of Amblyomma coelebs, $A$. ovale, A. parvum, A. sculptum and Ornithodoros mimon (SPONCHIADO et al.,2015).
For blood collection, all animals were anesthetized with an intramuscular injection (dosage $25 \mathrm{mgkg}^{-1}$ ) of Zoletil ${ }^{\circledR} 50$ (mixture of tiletamine and zolazepam, $25 \mathrm{mgmL}^{-1}$ of each), as previously described (RIVAS et al., 2015). Blood samples were collected by cardiac puncture and sera were separated by centrifugation (12,000 rcf-10 min). Rodent and marsupial sera were tested by indirect immunofluorescence assay (IFA) using crude antigens of 6 Rickettsia isolates from Brazil (R. rickettsii strain Taiaçu, R. parkeri strain At24, $\boldsymbol{R}$. amblyommii strain Ac37, R. rhipicephali strain HJ5, R. felis strain Pedreira, and $\boldsymbol{R}$. bellii strain Mogi), following previously described protocols (HORTA et al., 2004, 2007). Fluoresce in isothiocyanate- labelled goat anti-mouse IgG, dilution 1:400 (Sigma, St Louis, MO, USA) and sheep anti-opossum IgG, dilution 1:500 (CCZ, São Paulo, Brazil) were used as conjugate for rodent and marsupial sera, respectively. In each slide, a serum previously shown to be non-reactive (negative control) and a known reactive serum (positive control) were tested at the 1:64 dilution.

Overall, sera from 37.5\% (9/24) and 6.8\% (3/44) of the marsupials and rodents, respectively, were reactive to at least one Rickettsia antigen (Table 1). No seropositive small mammal showed an

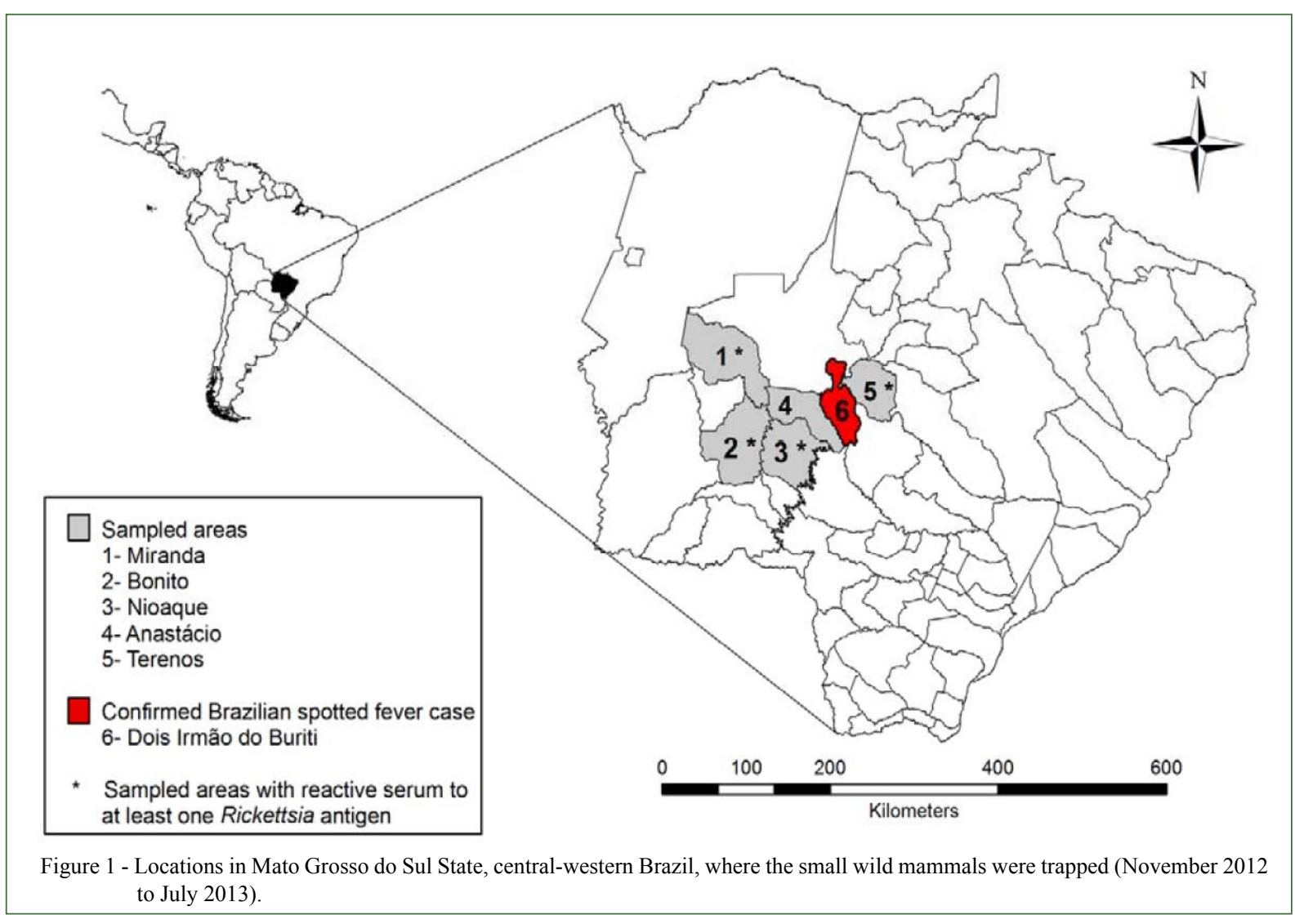

Ciência Rural, v.47, n.1, 2017. 
Table 1 -Results of sero reactivity of wild small mammals from MatoGrosso do Sul State, central- western Brazil to six Rickettsia species (November 2012 to July 2013).

\begin{tabular}{|c|c|c|c|c|c|c|c|}
\hline \multirow{3}{*}{ Animals } & \multirow{3}{*}{$\begin{array}{l}\text { Study area } \\
\text { (No. } \\
\text { positive/No. } \\
\text { tested) }\end{array}$} & \multicolumn{6}{|c|}{ No. of animals that reacted positively to the following Rickettsia species } \\
\hline & & \multicolumn{6}{|c|}{ (range of endpoint titres in parenthesis) } \\
\hline & & R. rickettsii & R.parkeri & R.rhipicephali & R.amblyommii & R.bellii & R.felis \\
\hline \multicolumn{8}{|l|}{ Rodents } \\
\hline \multirow{3}{*}{ Calomys callosus } & Bonito $(0 / 2)$ & 0 & 0 & 0 & 0 & 0 & 0 \\
\hline & Nioaque $(0 / 1)$ & 0 & 0 & 0 & 0 & 0 & 0 \\
\hline & Terenos $(0 / 3)$ & 0 & 0 & 0 & 0 & 0 & 0 \\
\hline Calomys tener & Terenos $(0 / 1)$ & 0 & 0 & 0 & 0 & 0 & 0 \\
\hline \multirow{2}{*}{ Cerradomys scotti } & Bonito $(0 / 2)$ & 0 & 0 & 0 & 0 & 0 & 0 \\
\hline & Terenos $(1 / 4)$ & $1(64)$ & 0 & 0 & 0 & $1(64)$ & 0 \\
\hline \multirow{2}{*}{ Cerradomys maracajuensis } & Miranda (1/1) & $1(256)$ & $1(128)$ & 0 & $1(64)$ & 0 & 0 \\
\hline & Terenos $(0 / 1)$ & 0 & 0 & 0 & 0 & 0 & 0 \\
\hline Hylaeamys megacephalus & Bonito (1/4) & 0 & 0 & 0 & $1(128)$ & 0 & 0 \\
\hline \multirow{2}{*}{ Nectomys rattus } & Miranda (0/1) & 0 & 0 & 0 & 0 & 0 & 0 \\
\hline & Terenos $(0 / 1)$ & 0 & 0 & 0 & 0 & 0 & 0 \\
\hline \multirow{4}{*}{ Oecomys bicolor } & Anastacio (0/1) & 0 & 0 & 0 & 0 & 0 & 0 \\
\hline & Bonito $(0 / 1)$ & 0 & 0 & 0 & 0 & 0 & 0 \\
\hline & Miranda $(0 / 1)$ & 0 & 0 & 0 & 0 & 0 & 0 \\
\hline & Terenos $(0 / 1)$ & 0 & 0 & 0 & 0 & 0 & 0 \\
\hline Oecomys mamorae & Bonito $(0 / 1)$ & 0 & 0 & 0 & 0 & 0 & 0 \\
\hline \multirow{5}{*}{ Rhipidomys macrurus } & Anastacio (0/5) & 0 & 0 & 0 & 0 & 0 & 0 \\
\hline & Bonito $(0 / 6)$ & 0 & 0 & 0 & 0 & 0 & 0 \\
\hline & Miranda $(0 / 1)$ & 0 & 0 & 0 & 0 & 0 & 0 \\
\hline & Nioaque $(0 / 4)$ & 0 & 0 & 0 & 0 & 0 & 0 \\
\hline & Terenos $(0 / 2)$ & 0 & 0 & 0 & 0 & 0 & 0 \\
\hline \multicolumn{8}{|l|}{ Marsupials } \\
\hline \multirow{4}{*}{ Didelphisalbiventris } & Anastacio (0/1) & 0 & 0 & 0 & 0 & 0 & 0 \\
\hline & Bonito $(1 / 2)$ & $1(64)$ & $1(512)$ & $1(128)$ & $1(512)$ & 0 & 0 \\
\hline & Nioaque $(5 / 6)$ & $3(128-256)$ & $1(128)$ & 0 & $2(128)$ & $1(64)$ & 0 \\
\hline & Terenos $(2 / 10)$ & $2(128-512)$ & $2(128-256)$ & $1(128)$ & $2(512)$ & 0 & 0 \\
\hline \multirow{3}{*}{ Gracilia usagilis } & Anastacio (0/1) & 0 & 0 & 0 & 0 & 0 & 0 \\
\hline & Bonito (1/1) & $1(256)$ & $1(64)$ & $1(256)$ & $1(512)$ & 0 & 0 \\
\hline & Terenos $(0 / 1)$ & 0 & 0 & 0 & 0 & 0 & 0 \\
\hline Marmosa murina & Terenos $(0 / 1)$ & 0 & 0 & 0 & 0 & 0 & 0 \\
\hline Thylamys macrurus & Bonito $(0 / 1)$ & 0 & 0 & 0 & 0 & 0 & 0 \\
\hline TOTAL & $12 / 68$ & $9(64-512)$ & $6(64-512)$ & $3(128-256)$ & $8(64-512)$ & $2(64)$ & 0 \\
\hline
\end{tabular}


end point titre to a Rickettsia species at least 4-fold higher than the titres exhibited to any of the other five rickettsial antigens, precluding any inference of which possible Rickettsia species infected these animals, as described by HORTA et al. (2004). The Fisher exact statistical test showed that these sororeactivity for SFG rickettsiae was significantly higher $(\mathrm{P}<0.05)$ among marsupials than small rodents, what is probably related to the fact that these marsupials had a much higher tick prevalence than small rodents (SPONCHIADO et al., 2015). This condition increases the likelihood of $\boldsymbol{D}$. albiventris being infested by a SFG rickettsia-infected ticks, when compared to the other small mammal species. Interestingly, this difference was also observed by SZABÓ et al. (2013) in the State of São Paulo. In addition, HORTA et al.(2009) showed that $\boldsymbol{D}$. aurita can act as amplifier host for $\boldsymbol{R}$. rickettsii, having an important role in the BSF epidemiology. Moreover, Didelphis spp. are considered excellent sentinels for BSF surveillance (HORTA et al., 2007).

This study is the first rickettsial sero survey of wild small mammals in the CentralWestern region of Brazil. Our results indicate that small mammals were exposed to SFG rickettsiae, suggesting that animals such as D. albiventris participate in the maintenance of the ecological cycle of SFG rickettsiae in these areas. The tick-borne agents that have been reported to cause disease in humans in Brazil are $\boldsymbol{R}$. rickettsii (ANGERAMI et al., 2006) and Rickettsia sp. strain Atlantic rainforest, a $\boldsymbol{R}$. parkeri-like agent (SPOLIDORIO et al., 2010). Even though it was not possible to infer the SFG Rickettsia species to which small mammals were exposed in the present study, our results highlighted the possibility that tick-borne zoonoses could be circulating between small rodents and ticks in Mato Grosso do Sul, Brazil. This assumption is supported by the fact that these rodents were infested by at least four tick species, A. coelebs, A. ovale, A. parvum and $\boldsymbol{A}$. sculptum (SPONCHIADO et al., 2015) that have been reported as infected by different SFG agents in Brazil, including the human pathogens $\boldsymbol{R}$. rickettsii and Rickettsia sp. strain Atlantic rainforest (LABRUNA et al., 2004;SZABÓ et al., 2013; NIERI-BASTOS et al., 2014; KRAWCZAK et al. 2014; WITTER et al. 2016).

\section{ACKNOWLEDGMENTS}

Fundação de Amparo a Pesquisa do Estado de São Paulo (FAPESP), Conselho Nacional de Desenvolvimento Científico e Tecnológico (CNPq) and Coordenação de Aperfeiçoamento Pessoal de Nível Superior (CAPES).

\section{BIOETHICS \\ AND COMMITTEE APPROVAL}

BIOSSECURITY

Protocol n. 30808-2

\section{REFERENCES}

ANGERAMI, R.N. et al. Brazilian Spotted Fever: a case series from an endemic area in Southeastern Brazil: clinical aspects. Annals of the New York Academy of Sciences, v.1078, p.252254, 2006. Available from: <http://onlinelibrary.wiley.com/ doi/10.1196/annals.1374.044/full>. Accessed: Nov. 04, 2015. doi: 10.1196/annals.1374.044.

BARBIERI, A.R.M. et al. Epidemiology of Rickettsia sp. strain Atlantic rainforest in a spotted fever-endemic area of southern Brazil. Ticks and Tick-borne Diseases, v.5, p.848-853,2014. Available from: $<$ http:/www.sciencedirect.com/science/article/pii/ S1877959X14001472>. Accessed: Nov. 04, 2015. doi: 10.1016/j. ttbdis.2014.07.010.

HORTA, M.C. et al. Prevalence of antibodies to spotted fever group Rickettsiae in humans and domestic animals in a Brazilian spotted fever endemic area in the state of São Paulo, Brazil: serological evidence for infection by Rickettsia rickettsii and another spotted fever group Rickettsia. American Society of Tropical Medicine and Hygiene, v.71, p.93-97,2004. Available from: <http://www. ajtmh.org/content/71/1/93.full.pdf+html>. Accessed: Nov. 05, 2015.

HORTA, M.C.et al. Rickettsia infection in five areas of the state of São Paulo, Brazil. Memórias do Instituto Oswaldo Cruz, v.102, p.793-801, 2007. Availablefrom: <http://www.ncbi.nlm.nih. gov/pubmed/18094887>. Accessed:Nov. 05, 2015. doi: 10.1590/ S0074-02762007000700003.

HORTA, M.C. et al.Experimental infection of opossums Didelphisaurita by Rickettsia rickettsii and evaluation of the transmission of the infection to ticks Amblyomma cajennense. Vector-borne and ZoonoticDiseases, v.9, p.109-118,2009. Available from: <http://online.liebertpub.com/doi/pdf/10.1089/vbz.2008.0114>. Accessed: Nov. 05, 2015. doi: 10.1089/vbz.2008.0114.

KRAWCZAK, F.S. et al. Rickettsial infection in Amblyommacajennense ticks and capybaras (Hydrochoerus hydrochaeris) in a Brazilian spotted fever-endemic area. Parasites \& Vectors, v.7, p.1-7, 2014. Available from: <http:// www.ncbi.nlm.nih.gov/pmc/articles/PMC3892071/pdf/17563305-7-7.pdf>. Accessed: May 12, 2016. doi: 10.1186/17563305-7-7.

LABRUNA, M. B. et al. Rickettsia bellii and Rickettsia amblyommii in Amblyomma Ticks from the State of Rondônia, Western Amazon, Brazil. Journal of Medical Entomology, v.41, p.1073-1081, 2004. Available from: <http://www.ncbi. nlm.nih.gov/pubmed/15605647>. Accessed: May 14, 2016. doi: 10.1603/0022-2585-41.6.1073.

LABRUNA, M.B. Ecology of Rickettsia in South America.Annals of the New York Academy of sciences, v.1166, p.156-166,2009. Available from: <http://onlinelibrary.wiley.com/doi/10.1111/ j.1749-6632.2009.04516.x/full>. Accessed: Nov. 05, 2015. doi: 10.1111/j.1749-6632.2009.04516.x.

MINISTÉRIO DA SAÚDE. Febre maculosa brasileira. Portal da Saúde, Brasília, 27 abril 2016. Situação Epidemiológica- 
Dados. Online .Available from: <http://portalsaude.saude.gov.br/ images/pdf/2016/abril/27/tabela-casos-febre-maculosa-2016.pdf $>$. Accessed: May 13, 2016.

NIERI-BASTOS F.A. et al. Candidatus Rickettsia andeanae, a spotted fever group agent infecting Amblyomma parvum ticks in two Brazilian biomes. Memórias do Instituto Oswaldo Cruz, v.109, p.259-261. 2014. Available from: <http://www.scielo.br/ pdf/mioc/v109n2/0074-0276-mioc-109-02-0276140283.pdf> Accessed: May 12, 2016. doi: 10.1590/0074-0276140283.

RIVAS, J.J. et al. Pathogenic potential of a Costa Rican strain of "Candidatus Rickettsia amblyommii" in guinea pigs (Cavia porcellus) and protective immunity against Rickettsia rickettsii.Ticks and Tick-borne Diseases, v.6, p.805-811, 2015. Available from: <http:// www.sciencedirect.com/science/article/pii/S1877959X15001387>. Accessed: May 01, 2016. doi: 10.1016/j.ttbdis.2015.07.008.

SARAIVA, D.G. et al. Ticks (Acari: Ixodidae) associated with small terrestrial mammals in the state of Minas Gerais, southeastern Brazil. Experimental and Applied Acarology, v.58, p.159-166, 2012. Available from: <http://link.springer.com/article/10.1007/ s10493-012-9570-9>. Accessed: Nov. 04, 2015. doi: 10.1007/ s10493-012-9570-9.
SPOLIDORIO, M.G. et al. Novel spotted fever group rickettsiosis, Brazil.Emerging Infectious Diseases, v.16, p.521-523,2010. Available from: <http://www.ncbi.nlm.nih.gov/pmc/articles/PMC3322033/> Accessed: Nov. 04, 2015. doi: 10.3201/eid1603.091338.

SPONCHIADO, J.et al. Association patterns of ticks (Acari: Ixodida: Ixodidae, Argasidae) of small mammals in Cerrado Fragments, western Brazil. Experimental and Applied Acarology, v.65, p.389-401,2015. Available from: <http://link.springer.com/ article/10.1007/s10493-014-9877-9>. Accessed: Nov. 04, 2015. doi: $10.1007 / \mathrm{s} 10493-014-9877-9$.

SZABÓ, M.P.J. et al. In vitro isolation from Amblyommaovale (Acari:Ixodidae) and ecological aspects of the Atlantic Rainforest Rickettsia, the causative agent of a novel spotted fever rickettsiosis in Brazil. Parasitology, v.140, n.6, p.719-728,2013. Available from: $<$ http://dx.doi.org/10.1017/S0031182012002065>. Accessed: Nov. 04, 2015 .doi: 10.1017/S0031182012002065.

WITTER, R. et al. Rickettsial infection in ticks (Acari: Ixodidae) of wild animals in midwestern Brazil. Ticks and Tick-borne Diseases, v.7, p.415-423,2016. Available from: <http://www. sciencedirect.com/science/article/pii/S1877959X15300601>. Accessed: May 12, 2016. doi: 10.1016/j.ttbdis.2015.12.019. 